\title{
Comparative microbial sampling from eutrophic caves in Slovenia and Slovakia using RIDA ${ }^{\circledR}$ COUNT test kits
}

\author{
Janez Mulec ${ }^{1}$, Václav Krištůfek ${ }^{2}$, and Alica Chroňáková ${ }^{2}$
}

\begin{abstract}
:
Mulec J., Krištůfek V. and Chroňáková A. 2012. Comparative microbial sampling from eutrophic caves in Slovenia and Slovakia using RIDA ${ }^{\circledR}$ COUNT test kits. Use of RIDA ${ }^{\circledR}$ COUNT in caves. International Journal of Speleology, 41 (1), 1-8. Tampa, FL (USA). ISSN 0392-6672. http://dx.doi.org/10.5038/1827-806X.41.1.1

RIDA®COUNT test plates were used as an easy-to-handle and rapid indicator of microbial counts in karst ecosystems of several caves in Slovakia and Slovenia. All of the caves had a high organic input from water streams, tourists, roosting bat colonies or terrestrial surroundings. We sampled swabs, water and air samples to test robustness and universality of the RIDA®COUNT test kit (R-Biopharm AG, Germany, http://www.r-biopharm.com/) for quantification of total bacteria, coliforms, yeast and mold. Using data from swabs (colony-forming units CFU per $\mathrm{cm}^{2}$ ) we proposed a scale for description of biocontamination level or superficial microbial load of cave niches. Based on this scale, surfaces of Ardovská Cave, Drienovská Cave and Stará Brzotínská Cave (Slovakia) were moderately colonized by microbes, with total microbial counts (sum of total bacterial count and total yeast and molds count) in the range of 1,001-10,000 CFU/100 $\mathrm{cm}^{2}$, while some surfaces from the show cave Postojna Cave (Slovenia) can be considered highly colonized by microbes (total microbial counts $\geq 10,001 \mathrm{CFU} / 100 \mathrm{~cm}^{2}$ ). Ardovská Cave also had a high concentration of airborne microbes, which can be explained by restricted air circulation and regular bat activity. The ratio of coliform to total counts of bacteria in the $9 \mathrm{~km}$ of underground Pivka River flow in Postojna Cave dropped approximately 4-fold from the entrance, indicating the high anthropogenic pollution in the most exposed site in the show cave. The RIDA®COUNT test kit was proven to be applicable for regular monitoring of eutrophication and human influence in eutrophic karst caves.
\end{abstract}

Keywords: caves; monitoring; air; water; speleothems; bacteria; fungi

Received 3 January 2011; Revised 17 February 2011; Accepted 15 March 2011

\section{INTRODUCTION}

Transport and handling of research equipment for detection of microorganisms during expeditions in the underground is inconvenient; therefore it is important to adopt a sensitive procedure and robust materials. The protocol should include appropriate microbial indicator groups, and it should be easy, reproducible and cost-efficient. For this study, we adopted the RIDA ${ }^{\circledR}$ COUNT test kit (R-Biopharm AG, Germany, http://www.r-biopharm.com/) for quantitative microbial detection to monitor underground water and air quality and to get an insight on viable microbes in eutrophic caves. RIDA ${ }^{\circledR}$ COUNT test has been used successfully in the dairy industry to find critical points where special attention or improved cleaning is needed (Salo et al., 2006). We tested the use of RIDA $^{\circledR}$ COUNT plates to count total aerobic and heterotrophic bacteria (RIDA ${ }^{\circledR}$ COUNT Total Aerobic Count), total number of coliform bacteria (RIDA ${ }^{\circledR}$ COUNT Coliform) and colony-forming units of

${ }^{1}$ Karst Research Institute, Scientific Research Centre of the Slovenian Academy of Sciences and Arts, Titov trg 2, 6230 Postojna, Slovenia (janez.mulec@guest.arnes.si)

${ }^{2}$ Institute of Soil Biology, Biology Centre of the Academy of Sciences of the Czech Republic, Na Sádkách 7, 37005 České Budějovice, Czech Republic (kristuf@upb.cas.cz), (alicach@upb.cas.cz) yeast and molds (RIDA ${ }^{\circledR}$ COUNT Yeast\&Mold Rapid) in the underground. Similar methodology was applied in the Cave of Altamira for enumerating total aerobic bacteria in dripping water using Petrifilm plates (Laiz et al., 1999).

In some rare cave ecosystems energy originates from in situ bacterial chemoautotrophy (e.g. Movile cave in Romania; Sârbu et al., 1996); however most caves depend on nutrient input originating from the cave exterior. Nutrients enter caves via underground rivers, penetrating plant roots, migrating animals, and percolation water (Culver \& Pipan, 2009). Along with nutrients, allochthonous microorganisms also enter caves, and due to their small size, they can easily penetrate deep underground in the form of bioaerosols, which are simply transported by air currents. Many microbes enter caves as airborne particles, while some become airborne in the underground, for example due to splashing water or local air currents caused by bat movements.

Heterotrophic microorganisms tend to colonize parts of caves where nutrients have been introduced, such as: areas near surface openings, underground rivers, sediments, and surfaces associated with animal excrement. Many caves naturally face increased input of organic matter, while others are subjected to high anthropogenic impact due to drainage 
of polluted water into the underground or extensive tourist visits of show caves (e.g. Kartchner Caverns, Arizona, USA; Ikner et al., 2007; and Lascaux Cave, Montignac, France; Bastian et al., 2009). For sanitary microbiology, caves in karst represent a natural window to monitor underground water conditions and accumulation of organic matter. The most important question for public safety is to locate the source of biological pollution, especially in those karst areas with well developed underground drainage systems.

Less discussed than microbiological water quality in the underground are cave airborne microbes. Air contains various inanimate particles, such as dust, and many viable propagules. This issue is especially urgent in caves with mass tourism. Humans each shed on average about seven million particles and cells per minute, and each of these particles carries an average of four microbial cells (Binnie, 1991). Furthermore, coughing and loud talking are reported to release approximately $10^{4}$ droplets, while sneezing releases approximately $10^{6}$ droplets (Stetzenbach, 1997), which can significantly increase the potential of transfer and deposition of pathogens in a cave ecosystem.

Laiz et al. (1999) found that dripping waters in Altamira cave (Spain) contain mainly gram-negative bacteria related to Enterobacteriaceae and Vibrionaceae. Other significant sources of airborne microorganisms are bat guano heaps and bats. Chroňáková et al. (2009) found as much as $1.6-3.9 \times 10^{10}$ total bacterial counts in 1 gram of bat guano (dry weight) deposited in Domica Cave (Slovak Karst National Park, Slovakia). The most static cave microhabitats are solid materials and surfaces subjected to microbial colonization. An insight on these cave microhabitats can be obtained by swabs. A swab of a particular site also gives us an idea of how microbes have been spread in a cave, for example by footprints of animals and humans.

The assurance of naturally occurring conditions should be in the focus of sustainable management of karst caves, especially for all caves in protected areas and caves listed as UNESCO World Heritage Sites (www.unesco.org). Here we present a list of different and suitable microhabitats and a methodology based on already existing and established protocols (AOAC Performance Tested Method ${ }^{\mathrm{SM}}$ status) that allow ecologists a rapid insight on microbiological load, eutrophic level and eventual biohazards in the underground.

\section{DESCRIPTION OF STUDIED CAVES}

One cave in Slovenia (Postojna Cave, 11 June 2009, 28 August 2009, 24-30 June 2010) and three caves in Slovakia (Ardovská Cave, Drienovská Cave, Stará Brzotínská Cave, 12-14 April 2010; Slovak Karst National Park, Slovakia) were studied. Background on the caves is summarized in Table 1 . Postojna Cave is part of the longest cave system in Slovenia (the whole system is $20,570 \mathrm{~km}$ long) with the underground Pivka River, and is partly equipped for tourist visits. This show cave is visited by approximately 500,000 tourists per year. Ardovská Cave, Drienovská Cave and Stará Brzotínská Cave are wild caves with roosting bat colonies; in addition in Drienovská Cave there is an active underground stream.

\section{MATERIAL AND METHODS}

\section{Cultivation-based analysis}

The RIDA ${ }^{\circledR}$ COUNT AOAC Performance tested Method $^{\mathrm{SM}} 100402$ (R-Biopharm AG, Germany) was used for enumeration of microorganisms in cave samples. The total counts of bacteria (RIDA ${ }^{\circledR}$ COUNT Total Aerobic Count, Fig. 1), conventional total coliform bacteria (RIDA ${ }^{\circledR}$ COUNT Coliform, Fig. 1), yeasts and molds (RIDA ${ }^{\circledR}$ COUNT Yeast\&Mold Rapid) were detected by the test. The principle behind the RIDA ${ }^{\circledR}$ COUNT test plates is generally based on cultivating microorganisms using standard nutrients combined with a specific chromogenic detection system (Morita et al., 2003). During the growth phase, microorganisms will form typical colonies whilst the presence of specific enzymes will change the originally colourless substrate to produce a distinctively coloured colony. All of the different products of the RIDA ${ }^{\circledR}$ COUNT line are suitable for the detection of microorganisms deriving from food or feed, contact samples, membrane filtration and air sampling systems (www.r-biopharm. com). Comparative recovery between the medium sheet and different agar or Petrifilm was conducted (Morita et al., 2003; Morita et al., 2006). The correlation co-efficient to plate count agar or Petrifilm in the internal accuracy studies were $0.94-0.99$.

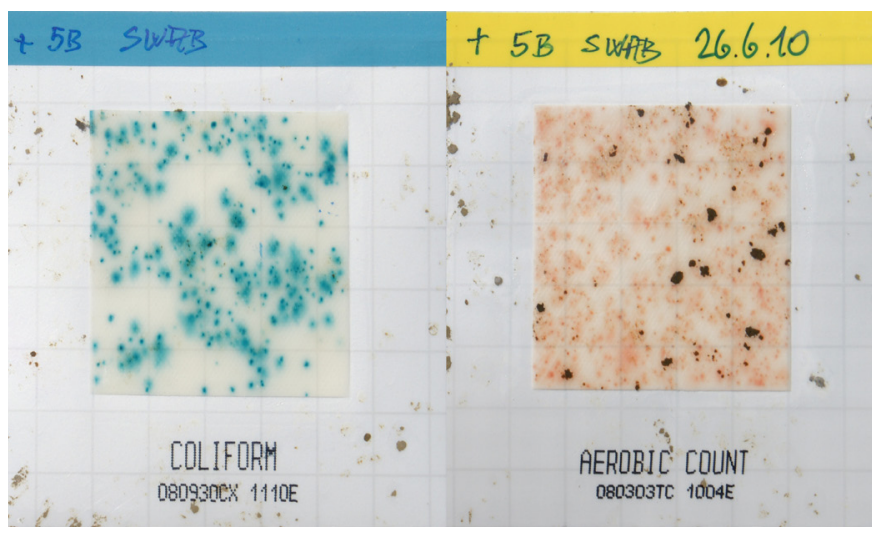

Fig. 1. Swab samples of sediment, regularly flooded by the underground Pivka River in Postojna Cave, after $48 \mathrm{~h}$ of incubation at $35^{\circ} \mathrm{C}$; left-RIDA ${ }^{\oplus} \mathrm{COUNT}$ Coliform, right- RIDA ${ }^{\oplus} \mathrm{COUNT}$ Total Aerobic Count.

\section{Sampling sites}

Various microhabitats were sampled in caves. To observe the potential impact of environmental gradient and influences from the surface, samples were taken from the cave entrance towards the interior of each cave, and in addition in Postojna Cave samples were taken in a heavily visited part and in a wild part deep in the cave. Three different types of samples were taken from all studied caves: air, swabs of solid surfaces and water.

\section{Air samples}

Air samples were taken simultaneously with measurement of atmospheric parameters, temperature, and relative humidity by a Kestrel 4500 Pocket Weather Tracker (USA). Samples for microbial counts 
were collected at various distances from cave openings and from bioaerosols formed by cave streams and aerosolized from guano heaps. A RIDA ${ }^{\circledR} \mathrm{COUNT}$ test kit was applied for air samples by a depositional sedimentation method when open RIDA ${ }^{\circledR}$ COUNT test plates were exposed to cave atmosphere for $20 \mathrm{~min}-$ utes. Microbial counts (colony-forming units, CFU) from depositional sampling on RIDA $^{\circledR}$ COUNT test plates $(4.7 \times 4.7 \mathrm{~cm})$ were recalculated per Petri plate (9 $\mathrm{cm}$ in diameter) per hour, allowing comparison with data of standard sanitary conditions for concentration of microorganisms in indoor air (Klánová, 2002). Two hours prior to air or swab sampling in a cave $1 \mathrm{ml}$ of sterile physiological solution (R-Biopharm AG, Germany) was applied on the sheet.

\section{Surface swab samples}

The most variable samples were swabs. In Ardovska Cave the following sampling locations were selected: cave wall covered with vermiculites (defined by Gèze, 1973), cave wall covered with black organic layer of bat guano, limestone bedrock along caving route, and a dry pond with animal excrement. In Drienovská Cave, the following samples were taken: dead wood with bat excrements, cave wall covered with a black organic layer originating from bat guano, and a wet stalagmite. In Postojna Cave we sampled a stainless steel fence touched by tourists at the cave entrance, concrete of a riverbed (in the past, the water course in this part of the cave was regulated with a barrier constructed to obtain a permanent lake at the ponor - where a surface stream flows underground in order to minimize external influences of the cave environment), the surface of sediments occasionally flooded by the underground Pivka River, a railroad tie of a tourist train inside the cave, a speleothem covered with dust, vermiculites, a stalagmite touched by tourists, the surface of a tourist trail, and a pristine untouched stalagmite. In Stará Brzotinská Cave swabs were taken from bedrock covered with aerophytic algae, from flowstone with seeping water and from "cave gold". The golden aspect of organic layer and microbial colonies usually appears when illuminated water droplets magnify the yellowish pigment of the microbial mat beneath the water film (Mulec, 2008). Surface swab samples $\left(20 \mathrm{~cm}^{2}\right)$ were taken aseptically in caves from solid surfaces with minimum irregularities.

\section{Water samples}

In Ardovská Cave and Stará Brzotínská Cave water samples were taken from pools filled with percolation water. In Drienovská Cave an underground river and karst spring were also sampled. In Postojna Cave the underground Pivka River was sampled at several sites along $9 \mathrm{~km}$ of the underground flow from the ponor in Postojna Cave till the underground stream confluence with the Rak River in Planina Cave. Basic physical parameters of the water (temperature, specific electric conductivity-SEC, $\mathrm{pH}$ ) were measured with the use of WTW Multiline P4 equipment. At the site $1 \mathrm{ml}$ of water specimen was directly applied with a sterile plastic Pasteur pipette onto the RIDA ${ }^{\circledR}$ COUNT growth medium surface.

\section{Analysis and reading results}

All samples were applied onto $\mathrm{RIDA}^{\circledR} \mathrm{COUNT}$ plates at the place of sampling in a cave. In the laboratory plates were incubated at $35^{\circ} \mathrm{C}$ for $24-48$ hours for total aerobic and coliform bacteria counts, and at $25^{\circ} \mathrm{C}$ for $48-72$ hours for yeast and molds counts. Twenty-four hours of prolonged cultivation according to the user's manual (R-Biopharm AG) gave higher numbers of viable bacteria. Microbial colonies were enumerated and expressed as colony-forming units (CFU) per surface $\left(100 \mathrm{~cm}^{2}\right)$ or volume unit (ml).

\section{Statistical evaluation}

Pearson's correlation and dependence were calculated between physical parameters among microhabitats (air and water samples) and microbial counts. Relative standard error (RSE) was calculated to evaluate the repeatability on natural water samples from the underground Pivka River from Postojna Cave for the RIDA ${ }^{\circledR}$ COUNT Total Aerobic Count and RIDA ${ }^{\circledR}$ COUNT Coliform.

\section{RESULTS}

Total bacterial count, counts of coliform bacteria and yeast and mold counts expressed as CFU per volume or surface unit were used as a measure to compare various habitats between wild and show caves. All selected caves had high organic input of different origin. A large fraction of organic input in Postojna Cave originates from the Pivka River and tourist activities. The presence of bat colonies and guano in Slovak caves was the source of another type of organic input there (Table 1).

Limit values of airborne microorganisms for residential rooms are 50 bacterial CFU/Petri dish/ hour and 50 fungal CFU/Petri dish/hour (Klánová, 2002), corresponding approximately to the secondary category of pollution by EUR 14988 EN (Verhoeff, 1993) which corresponds to fewer than 500 bacterial $\mathrm{CFU} / \mathrm{m}^{3}$ and fewer than 500 molds $\mathrm{CFU} / \mathrm{m}^{3}$ (Klánová, 2002). The standard sanitary limit was significantly exceeded in all studied caves in the following order: Ardovská Cave > Drienovská Cave > Postojna Cave > Stará Brzotínská Cave. Depositional sedimentation for airborne microbiota showed that Ardovská Cave had the highest number of viable bacteria in the air (10-298 CFU/Petri dish/hour) and the second highest count of yeast and molds (29-115), but sampling was performed with very short distances between sampling stations (Table 2). We found low total bacterial counts and no statistically significant correlations between microbial counts and environmental air parameters in Postojna Cave, which can be attributed to its large size and huge underground galleries. As expected, airborne concentrations of coliform bacteria were zero except in places with evident and fresh organic inputs such as bat guano (Ardovská Cave) or organically polluted underground stream (Postojna Cave). Yeasts and molds were detected in higher concentrations in smaller and poorly ventilated caves in descending order: Ardovská Cave, Drienovská Cave, and Stará Brzotínská Cave. Analyses of variances showed that in smaller cave systems particular 
Table 1. Location and characterization of the caves in this study (Only Stará Brzotínská Cave is not gated).

\begin{tabular}{|c|c|c|c|c|c|c|c|c|c|}
\hline Cave & Geographic coordinates ${ }^{\mathrm{a}}$ & $\begin{array}{l}\text { Altitude }^{\text {a }} \\
\text { (m a.s.l.) }\end{array}$ & $\begin{array}{l}\text { Length }^{\mathrm{a}} \\
\text { (m) }\end{array}$ & $\begin{array}{c}\text { Air } \\
\text { temperature } \\
\left({ }^{\circ} \mathrm{C}\right)\end{array}$ & $\begin{array}{c}\text { Relative } \\
\text { humidity } \\
(\%)\end{array}$ & $\begin{array}{l}\text { Underground } \\
\text { stream }\end{array}$ & Plant cover & $\begin{array}{c}\text { Number of } \\
\text { bats }^{a}\end{array}$ & $\begin{array}{r}\text { Visitors } \\
\text { (per year) }\end{array}$ \\
\hline $\begin{array}{l}\text { Ardovská } \\
\text { Cave }\end{array}$ & $48^{\circ} 52^{\prime} 14^{\prime \prime N}, 20^{\circ} 42^{\prime} 09^{\prime \prime} \mathrm{E}$ & 314 & 1,492 & $8.0-11.5$ & 97.8 & No & $\begin{array}{l}\text { Deciduous } \\
\text { forest }\end{array}$ & Max. 200 & Wild cave \\
\hline $\begin{array}{l}\text { Drienovská } \\
\text { Cave }\end{array}$ & $48^{\circ} 62^{\prime} 48^{\prime \prime N}, 20^{\circ} 95^{\prime} 22^{\prime \prime} \mathrm{E}$ & 245 & 1,348 & $8.9-11.3$ & $94.5-100.0$ & Yes & $\begin{array}{l}\text { Deciduous } \\
\text { forest }\end{array}$ & $900-2,000$ & Wild cave ${ }^{b}$ \\
\hline $\begin{array}{l}\text { Postojna } \\
\text { Cave }\end{array}$ & $45^{\circ} 47^{\prime} 0.43^{\prime \prime} \mathrm{N}, 14^{\circ} 12^{\prime} 10.09^{\prime \prime} \mathrm{E}$ & 529 & 20,570 & $10.5-13.2$ & $88.3-100.0$ & Yes & $\begin{array}{l}\text { Forest, } \\
\text { shrubs }\end{array}$ & Transitory & 500,000 \\
\hline $\begin{array}{l}\text { Stará Brzotínská } \\
\text { Cave }\end{array}$ & $48^{\circ} 60^{\prime} 89^{\prime \prime} \mathrm{N}, 20^{\circ} 47^{\prime} 04^{\prime \prime} \mathrm{E}$ & 258 & 120 & $9.5-10.2$ & $95.0-99.3$ & Occasionally & $\begin{array}{l}\text { Deciduous } \\
\text { forest }\end{array}$ & $15-27$ & Wild cave $^{b}$ \\
\hline
\end{tabular}

aData according to the Slovak Caves Administration (Liptovský Mikuláš, Slovakia), Hapl et al., (2002); Matis, (2002), and Cave Cadastre of the Karst Research Institute at ZRC SAZU and the Speleological Association of Slovenia.

${ }^{\mathrm{b} O c c a s i o n a l l y ~ v i s i t e d ~ b y ~ s p e l e o l o g i s t s ~ a n d / o r ~ a r c h a e o l o g i s t s . ~}$

Table 2. Ranges of microbial count expressed as colony-forming units (CFU per Petri plates and 20 minutes of Ridacount test plate exposition; after 24,48 and /or 72 hours of plate incubation) for air quality, with indicated number of stations per cave.

\begin{tabular}{|c|c|c|c|c|c|c|c|c|}
\hline \multirow[b]{3}{*}{ Cave } & \multirow[b]{3}{*}{ Stations } & \multicolumn{7}{|c|}{ CFU/Petri plates/hour } \\
\hline & & \multicolumn{2}{|c|}{$\begin{array}{c}\text { Total aerobic } \\
\text { count of bacteria }\end{array}$} & \multicolumn{2}{|c|}{$\begin{array}{l}\text { Coliform } \\
\text { bacteria }\end{array}$} & \multicolumn{3}{|c|}{ Yeast \& molds } \\
\hline & & $24 \mathrm{~h}$ & $48 \mathrm{~h}$ & $24 \mathrm{~h}$ & $48 \mathrm{~h}$ & $24 \mathrm{~h}$ & $48 \mathrm{~h}$ & $72 \mathrm{~h}$ \\
\hline Ardovská Cave & 4 & $0-172$ & $10-298$ & 0 & $0-38$ & $0-10$ & $10-48$ & $29-115$ \\
\hline Drienovská Cave & 3 & $0-29$ & $19-67$ & 0 & 0 & $0-29$ & $0-154$ & $0-182$ \\
\hline Postojna Cave & 10 & $0-29$ & $0-86$ & $0-10$ & $0-10$ & 0 & 0 & 10 \\
\hline Stará Brzotinská Cave & 3 & $10-29$ & $19-48$ & $\mathrm{~N}$ & $\mathrm{~N}$ & $0-10$ & $0-10$ & $0-77$ \\
\hline
\end{tabular}

$\mathrm{N}$-not tested

aMicrobial counts (colony-forming units) in air detected on RIDA®COUNT test plates $(4.7 \times 4.7 \mathrm{~cm}$, exposure time 20 minutes) were recalculated per one Petri plate $(9 \mathrm{~cm}$ in diameter) per hour.

atmospheric parameters can have a notable effect on microbial distribution. For example, the correlation between temperature and yeast and mold counts in Stará Brzotinská Cave was $\mathrm{R}^{2}=0.99(\mathrm{p}=0.04$, total cave length $120 \mathrm{~m}$, Table 1).

Swabs of surfaces with obviously high organic material had high microbial counts. For example the surface of a speleothem with animal droppings had a total aerobic count of 2,285 bacterial CFU/100 $\mathrm{cm}^{2}$ (Ardovská Cave), a bedrock of riverbed with attached guano showed 65 coliform bacteria and dead wood had greater than 2,500 CFU/100 $\mathrm{cm}^{2}$ of yeast and mold (Drienovská Cave) (Table 3). The highest detected density of microbes per surface area was in the show cave Postojna Cave, primarily from swabs taken from the surface of tourist trails and frequently touched speleothems. Swabs of tourists' footprints showed counts of up to 15,100 total aerobic bacteria and 825 coliform bacteria $\left(\mathrm{CFU} / 100 \mathrm{~cm}^{2}\right)$ (Table 3). Sediments regularly flooded by the underground Pivka River were also rich in viable bacteria, including coliform bacteria (Fig 1). Bacterial counts from an untouched stalagmite $\left(15 \mathrm{CFU} / \mathrm{cm}^{2}\right)$ were lower from a touched stalagmite by 30 -fold. Besides yeast and mold, tourists also spread coliform bacteria in a show cave. Coliform bacteria in the tourist part of caves might indicate their origin from human and/or animal pollution, which raises an important biohazard issue.

RIDA ${ }^{\circledR}$ COUNT test kits were also successfully applied to assess water quality of the underground Pivka River (highly eutrophic) in the Postojna-Planina Cave System and Drienovská stream (Drienovská Cave, less eutrophic) in the National Park Slovak Karst (Table 4, Fig. 2). Kits were proven to be a reliable field test to determine quickly the possible existence of water contamination for public health. To evaluate the repeatability on natural water samples RSE (two sampling with triplicates) was calculated for samples from the underground Pivka River (Postojna Cave). When using RIDA ${ }^{\circledR}$ COUNT Total Aerobic RSE ranged from $1-5 \%$ and for the RIDA ${ }^{\circledR}$ COUNT Coliform from 3-6\%. These results showed that RIDA ${ }^{\circledR}$ COUNT test plates are satisfactory when we want to get a quick insight into the microbial status of the underground water quality; however this ready-to-use kit cannot completely substitute for classical microbiological media, because variety of commercial kits to detect different groups of microbes is rather limited.

To establish water quality we enumerated total aerobic counts of bacteria and the number of coliform bacteria. The Pivka River is a highly eutrophic river at the ponor in Postojna Cave regarding both total 
aerobic counts of bacteria and coliform bacteria. After the polluted Pivka sank in the cave the number of bacteria started to decrease, together with the ratio of coliforms to total bacterial counts. The highest ratio at the ponor was 0.80 , which after $9 \mathrm{~km}$ of underground water flow dropped to 0.2 (Fig. 2). The ratio of coliform to total counts of bacteria in the underground Pivka River in Postojna Cave in the summer period with low discharge ranged from 0.17 to 0.80 . In this regard, it should be taken into account that microbial count in underground streams is a reflection of many different interactions, such as dilution, mineralization, predation, etc. Temperature gradient was established along the groundwater flow, but statistically significant correlations between measured physical parameters and microbial counts were obtained only occasionally; for example on 11 June 2009, the Pearson correlation coefficient between specific electric conductivity and count of coliform bacteria was 0.967 ( $p=0.033)$. By using an alternative method of impacting to depositional air sampling (28 August 2009, impactor Mas100 , Merck) it was shown that high concentrations of coliform bacteria ( $>560 \mathrm{CFU} / \mathrm{ml}$ ) in the river resulted in aerosolization, and consequently formation of 2.8 $\mathrm{CFU} / \mathrm{m}^{3}$ of airborne coliform bacteria in the cave air (Mulec, 2010). Alternatively, by depositional sampling on 25 June 2010 we found in air 1 coliform bacterium (CFU/20 $\left.\mathrm{cm}^{2} / 20 \mathrm{~min}\right)$.

The studied part of the underground Drienovská stream was only $0.52 \mathrm{~km}$, and number of total bacterial count decreased with increasing distance of sampling sites upstream from the spring (Table 4).

Captured underground water in caves rich with bat guano had higher microbial counts compared to a cave with low organic input, with the highest numbers in Ardovská Cave (172 CFU/ml), followed by Drienovská Cave (maximum $168 \mathrm{CFU} / \mathrm{ml}$ ) and finally by Stará Brzotínská Cave (44 CFU/ml). The numbers of total aerobic bacteria in percolation water in Drienovská Cave were as high as $87 \mathrm{CFU} / \mathrm{ml}$ (Table 4).

\section{DISCUSSION}

In this study, we tested the versatility and potential use of RIDA ${ }^{\circledR}$ COUNT plates in the underground. The selected commercially available test plates reveal only part of chemoheterotrophic microorganisms in eutrophic environments. In general, only about $1 \%-$ $10 \%$ of the microorganisms in soil could be accessed by culturing and great majority of microorganisms from the environment cannot be grown in culture (van Elsas et al., 2006). Nevertheless, the use of cultural enrichment techniques has its place where selective media are required to demonstrate the presence, and possibly the magnitude, of particular microorganisms in a system, and it has been proven that such expression is representative and relevant to the objectives of the study (Ritz, 2007). For this study we selected caves which all have high organic input either from water streams, tourist visits, roosting bat colonies, or inputs from the surface. In caves we sampled microhabitats that reflect high organic load, and on the other hand, we also sampled in the same caves microhabitats that have low microbial abundance and face low impact from the cave exterior.
In all studied caves we sampled swabs, water (if present), and air. Although RIDA $^{\circledR}$ COUNT test plates were not initially designed for use in the underground, the results of their application in the underground showed that they can be easily applied in extreme environments, especially due to their easy handling and small size. Plates can be used to determine organic load indirectly by viable microbial counts in the underground and, with proper selection and application, also the biohazard level. For future use of RIDA ${ }^{\circledR}$ COUNT test plates in underground cave microbiology we propose to adopt $24 \mathrm{~h}$ prolonged cultivation according to the user's manual of the producer. Additional $24 \mathrm{~h}$ incubation revealed higher microbial counts and probably gives more realistic viable microbial counts, because some cave microbes showed slow growth on selected media.

The first insight into microbiological conditions in cave air can be revealed using depositional sampling. Conditions in cave atmosphere can vary a lot, especially close to cave openings, underground streams, or bat colonies. More stable atmospheric conditions in the underground are in small caves and caverns, and when the atmosphere in such spaces is not disturbed, a gradient of airborne microorganisms can be observed, for example reflecting the temperature gradient. On the other hand, depositional sampling can give first information whether any kind of disturbances recently appeared in the cave atmosphere.

From a biohazard point of view it is worthwhile to stress that once coliform bacteria (indicators of faecal pollution) or other potential pathogenic microbes, originating either from bat guano or polluted underground streams, reach the underground, they can become aerosolized and can travel substantial distances. They can migrate to different parts in a cave, but to a lesser extent in smaller caves, especially those with no active air movements. RIDA ${ }^{\circledR}$ COUNT test plates revealed higher amounts of total aerobic bacteria and coliforms in Ardovská Cave in comparison to other caves (Table 2). Similarly, the highest numbers

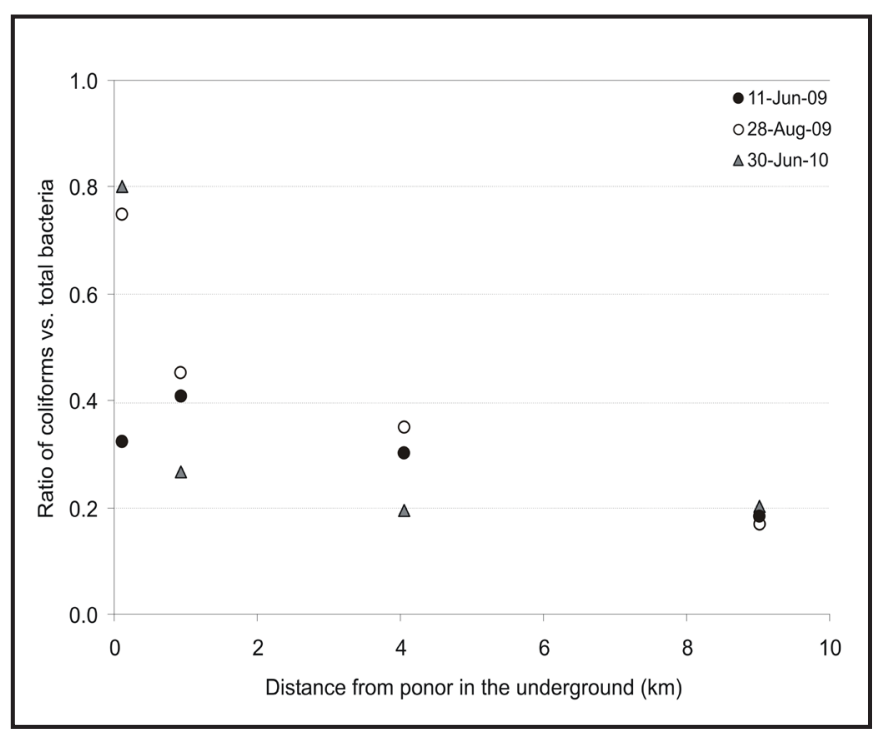

Fig. 2. Ratio of coliform bacteria to total aerobic bacteria (RIDA $®$ COUNT test plates) in Postojna-Planina Cave System from the underground flow of the Pivka River from the ponor in Postojna Cave to the spring in Planina Cave. 
of yeasts and molds were observed in Ardovská Cave together with Drienovská Cave (Table 2).

We collected swabs of various surfaces for microbial count estimation (Table 3). Swabs are frequently analysed in food and pharmaceutical industries to test for microbial contamination and the presence of pathogenic microbes. In this respect there are several guidelines how to sample and analyse and for the critical values of microbial biomass detected in swab samples (e.g. APHA - American Public Health Association or HACCP - Hazard Analysis Critical Control Point). For example, in the diary industry it is suggested that the total bacterial count should not exceed $10 \mathrm{CFU} / 100 \mathrm{~cm}^{2}$ and the coliform count $0 \mathrm{CFU} / 100 \mathrm{~cm}^{2}$ (Gavron \& Luck, 1990). For defining the degree of hazard or biocontamination level a logarithmic scale is frequently used, for example up to $10 \mathrm{CFU} / 100 \mathrm{~cm}^{2}$ represents biocontamination level 4, $\leq 100 \mathrm{CFU} / 100 \mathrm{~cm}^{2}$ represents level $3, \leq 1,000 \mathrm{CFU} / 100 \mathrm{~cm}^{2}$ represents level 2, and $\leq 10,000 \mathrm{CFU} / 100 \mathrm{~cm}^{2}$ indicates level 1. Based on field results we propose a similar gradation for superficial microbial load in the underground: numbers $\leq 100$ total CFU / $100 \mathrm{~cm}^{2}$ represent low level of microbially colonized surfaces, 101-1,000 CFU/100 $\mathrm{cm}^{2}$ represent low-medium, 1001-10,000 CFU/100 $\mathrm{cm}^{2}$ represent medium, and $\geq 10,001 \mathrm{CFU} / 100 \mathrm{~cm}^{2}$ represent high level of surface colonization by $\mathrm{mi}-$ crobes. To evaluate the different surfaces, representing specific habitats we summed up total bacterial count after $48 \mathrm{~h}$ and total fungal counts after 72 $\mathrm{h}$ (Table 3). Based on the scale above, swab surfaces from Ardovská Cave, Drienovská Cave and Stará Brzotinská Cave (Slovakia) fell in the range between 1,001-10,000 of total microbial counts/100 $\mathrm{cm}^{2}$, which indicated a medium level of surface colonization. One swab from Postojna Cave (tourist trail) exceeded 10,001 total $\mathrm{CFU} / 100 \mathrm{~cm}^{2}$, which indicates that some surfaces in this cave can be considered densely colonized by microorganisms. Generally, in Postojna Cave, the total microbial counts of swabs varied (Table 3).

Table 3. Swab analyses of microorganisms from various cave surfaces expressed as colony- forming units (CFU per surface unit; after 24, 48 and /or 72 hours of plate incubation; TOTAL represents the sum of total aerobic count of bacteria after $48 \mathrm{~h}$ and total yeasts and molds after $72 \mathrm{~h}$ ).

Cave (CFU/100 $\left.\mathrm{cm}^{2}\right)$

\begin{tabular}{|c|c|c|c|c|c|c|c|}
\hline \multirow[t]{2}{*}{ Swab type } & $\begin{array}{c}\text { Total Aerobic } \\
\text { count of bacteria }\end{array}$ & \multicolumn{2}{|c|}{$\begin{array}{l}\text { Coliform } \\
\text { bacteria }\end{array}$} & \multicolumn{3}{|c|}{ Yeasts and molds } & \multirow[t]{2}{*}{ TOTAL } \\
\hline & $24 \mathrm{~h} \quad 48 \mathrm{~h}$ & $24 \mathrm{~h}$ & $48 \mathrm{~h}$ & $24 \mathrm{~h}$ & $48 \mathrm{~h}$ & $72 \mathrm{~h}$ & \\
\hline
\end{tabular}

Bedrock with organic layer

Bedrock with vermiculites

Rock with partly digested guano

Speleothem with animal droppings

Bedrock of riverbed with attached guano

Stalagmite, humid

Wood with guano particles

\section{Bedrock with vermiculites}

Concrete, tourist trail in cave entrance

Concrete, tourist trail inside cave

Metal fence, touched

Riverbed, concrete occasionally flooded

Sediment, regularly flooded by underground river

Speleothem covered with dust

Stalagmite, touched

Stalagmite, untouched

Stalagmite, wet

Wood, railroad tie

Bedrock colonized by aerophytic algae

Bedrock with seeping water

Microbial mat attached on speleothem

$\begin{array}{cc}725 & 785 \\ 74 & 166 \\ 915 & 1,060 \\ 2,065 & 2,285\end{array}$

$\begin{array}{cc}350 & 620 \\ 95 & 245 \\ 10 & 55\end{array}$

15

260

15,100

15

3,385

5,250

130

390

0

0

300

55
2,290
15,100
30
3,660
5,250
190
455
15
0
820

0
0
135
5

\section{Ardovská Cave}

$\begin{array}{ccccr}0 & 0 & 30 & 125 & 910 \\ 15 & 15 & 28 & 83 & 249 \\ 320 & 15 & 155 & 175 & 1,225 \\ 35 & 0 & 130 & 170 & 2,455\end{array}$

\section{Drienovská Cave}

$\begin{array}{cccccr}20 & 65 & 0 & 55 & 65 & 685 \\ 0 & 55 & 0 & 60 & 105 & 350 \\ 0 & 0 & 875 & 1,000 & >2,500 & 2,550\end{array}$

\section{Postojna Cave}

$\begin{array}{cccccr}0 & 0 & 0 & 25 & 150 & 205 \\ 5 & 60 & 5 & 105 & 115 & 2,405 \\ 655 & 825 & 0 & 515 & 645 & 15,745 \\ 0 & 0 & 0 & 5 & 10 & 40 \\ 2,860 & 3,290 & 625 & 695 & 720 & 4,380 \\ 20 & 1,210 & 0 & 0 & 0 & 5,250 \\ 0 & 0 & 0 & 140 & 305 & 495 \\ 0 & 0 & 225 & 725 & 1,060 & 1,515 \\ 0 & 0 & 0 & 0 & 0 & 15 \\ 0 & 0 & 0 & 0 & 5 & 5 \\ 0 & 15 & 35 & 125 & 255 & 1,075\end{array}$

\section{Stará Brzotinská Cave}

\begin{tabular}{llcccccr}
210 & 260 & $\mathrm{~N}$ & $\mathrm{~N}$ & $>2,500$ & $>2,500$ & $>2,500$ & 2,760 \\
320 & 495 & 145 & 190 & 15 & 85 & 125 & 620 \\
305 & 355 & $\mathrm{~N}$ & $\mathrm{~N}$ & 5 & 45 & 55 & 410 \\
\hline
\end{tabular}


Table 4. Physical parameters of water bodies in caves and microbial counts expressed as colony-forming units (CFU per one millilitre; after 24,48 and /or 72 hours of plate incubation).

\begin{tabular}{|c|c|c|c|c|c|c|c|c|c|c|}
\hline \multirow[b]{4}{*}{ Water body } & \multicolumn{10}{|c|}{ Cave } \\
\hline & \multirow{3}{*}{$\frac{\mathrm{T}}{\left({ }^{\circ} \mathrm{C}\right)}$} & \multirow{3}{*}{$\frac{\mathrm{SEC}}{(\mu \mathrm{S} / \mathrm{cm})}$} & \multicolumn{3}{|c|}{$\begin{array}{cc} & \text { Total aerobic } \\
\mathrm{pH} \quad \text { count of bacteria }\end{array}$} & \multirow{2}{*}{\multicolumn{2}{|c|}{$\begin{array}{c}\begin{array}{c}\text { Coliform } \\
\text { bacteria }\end{array} \\
\text { (CFU/ml) }\end{array}$}} & \multicolumn{3}{|c|}{ Yeast and molds } \\
\hline & & & & & & & & & & \\
\hline & & & & $24 \mathrm{~h}$ & $48 \mathrm{~h}$ & $24 \mathrm{~h}$ & $48 \mathrm{~h}$ & $24 \mathrm{~h}$ & $48 \mathrm{~h}$ & $72 \mathrm{~h}$ \\
\hline & & & & & dovská & Cave & & & & \\
\hline \multirow[t]{2}{*}{ Captured underground water } & $\mathrm{N}$ & $\mathrm{N}$ & N & 121 & 172 & $\mathrm{~N}$ & $\mathrm{~N}$ & 0 & 4 & 29 \\
\hline & \multicolumn{10}{|c|}{ Drienovská Cave } \\
\hline Karst spring & 9.8 & 600 & 7.15 & 91 & 168 & 0 & 30 & 0 & 2 & 9 \\
\hline Underground river, $0.29 \mathrm{~km}$ upstream from spring & 9.6 & 578 & 7.09 & 7 & 34 & 0 & 1 & 0 & 0 & 0 \\
\hline Underground river, $0.52 \mathrm{~km}$ upstream from spring & 9.4 & 598 & 7.08 & 0 & 0 & 0 & 0 & 0 & 1 & 1 \\
\hline \multirow[t]{2}{*}{ Percolation water } & 9.9 & 678 & 7.04 & 39 & 87 & 1 & 7 & 0 & 30 & 34 \\
\hline & \multicolumn{10}{|c|}{ Postojna Cave } \\
\hline Ponor river & 16.6 & 438 & 7.74 & 364 & 434 & 290 & 349 & 0 & 3 & $\mathrm{~N}$ \\
\hline Underground river, $0.95 \mathrm{~km}$ downstream from ponor & 16.2 & 437 & 7.84 & 234 & 275 & 32 & 74 & 0 & 0 & $\mathrm{~N}$ \\
\hline Underground river, $4.06 \mathrm{~km}$ downstream from ponor & 14.2 & 423 & 8.02 & 167 & 204 & 5 & 40 & 1 & 1 & $\mathrm{~N}$ \\
\hline \multirow[t]{2}{*}{ Underground river, $9.02 \mathrm{~km}$ downstream from ponor } & 11.8 & 400 & 7.85 & 138 & 184 & 8 & 37 & 0 & 2 & $\mathrm{~N}$ \\
\hline & \multicolumn{10}{|c|}{. } \\
\hline Captured underground water & 8.8 & 520 & 7.25 & 10 & 44 & 0 & 1 & 0 & 0 & 9 \\
\hline
\end{tabular}

N-not tested

For assessment of drinking water quality several standards and reports are used worldwide (Canada, European Union, United Kingdom, South Africa, United States) including international standards to detect crucial microbiological parameters (Escherichia coli, coliform bacteria, enterococci, Clostridium perfringens, number of colonies at $22^{\circ} \mathrm{C}$, total number of colonies at $37^{\circ} \mathrm{C}$ etc.). Water quality regulated by International Organization for Standardization (ISO) is covered in the section ICS 13.060: Water quality (www.iso.org). These standards can be adopted also when using RIDA ${ }^{\circledR}$ COUNT test plates. To enumerate total bacteria, application of $1 \mathrm{ml}$ of tested water was sufficient for counting. For coliforms and yeast and mold counts, the application of $1 \mathrm{ml}$ of water sometimes resulted in no growth (Table 4). Coliforms are usually screened in a volume of $100 \mathrm{ml}$ (BS EN ISO 9308-1, 2007); however if there was a high number of coliforms in the sample, a volume of $1 \mathrm{ml}$ was enough to enumerate bacterial colonies.

In summary, surfaces in Ardovská Cave, Drienovská Cave and Stará Brzotinská Cave (Slovakia) shown medium level of microbial colonization. The tourist section of Postojna Cave (Slovenia) can be considered highly colonized by microbes. In addition, Ardovská Cave had a high concentration of airborne microbes, including total coliforms, yeasts and molds, which can be explained by restricted air circulation and regular bat activity, such as migration, roosting, and defecation.

\section{CONCLUSIONS}

RIDA ${ }^{\circledR}$ COUNT test plates (R-Biopharm AG, Germany) were successfully used as an alternative method (ISO standards) to plate count agar, allowing microbial ecologists a rapid insight on microbiological load, trophic level and eventual biohazards in the underground. They represent a valuable and robust tool for monitoring of microbial pollution in caves, easy to use and manipulate in the inconvenient conditions of the cave environment, and easy to read and evaluate test on plates in laboratory conditions. In our experiences, RIDA ${ }^{\circledR}$ COUNT plates have the potential for expanded use in detection of microbes in various eutrophic niches in caves and mines, in different underground water bodies, and from solid surfaces.

\section{ACKNOWLEDGEMENTS}

The study was supported by the Research Plans of ISB AS CR (no. AVOZ 60660521), MEYS CR (no. LC06066), Operation Program-Life Habitat (no. 241501120041), Research Programme "Karst Research P6-0119" (Slovenia). The authors acknowledge the Slovak Caves Administration in Liptovsky Mikuláš (Slovak Republic) for the research permit and cave data and are grateful to S. Glažar, A. Oarga, N. Ravbar, J. Turk and J. Walochnik for field assistance. We thank E. D. Covington for terminology assistance.

\section{REFERENCES}

Bastian F., Alabouvette C. \& Saiz-Jimenez C., 2009 - Bacteria and free-living amoeba in the Lascaux Cave. Research in Microbiology, 160: 38-40. http://dx.doi.org/10.1016/j.resmic.2008.10.001

Binnie P.W.H., 1991 - Biological pollutants in the indoor environment. In: Kay J.G., Keller G.E. \& Miller J.F. (Eds.) - Indoor air pollution, radon, bioaerosols, \& VOC. Lewis Publishers: 13-24. 
BS EN ISO 9308-1, 2007 - Water quality - Detection and enumeration of Escherichia coli and coliform bacteria Part 1: Membrane filtration method.

Chroňáková A., Horák A., Elhottová D. \& Krištůfek V., 2009 - Diverse archaeal community of a bat guano pile in Domica Cave (Slovak Karst, Slovakia). Folia Microbiologica, 54: 436-446.

Culver D.C. \& Pipan T., 2009 - The biology of caves and other subterranean habitats. Oxford University Press, Oxford, 254 p.

Gavron H. \& Luck H., 1990 - Quality control in dairy industry. In: Robinson R.K (Ed.) - Dairy microbiology. Vol. 2, Chapman \& Hall: 345-392.

Gèze B., 1973 - Lexique des termes français de spéléologie physique et de karstologie. Annales de Spéléologie, 28: 1-20.

Hapl E., Uhrin M., Bobáková L., Benda P., Andreas M., Reiter A., Hotový J., Obuch J., Stankovič J. \& Cselényi K., 2002 - Overview of wintering bats in Silická and Plešivecká plains. Vespertilio, 6: 193211. [In Slovak with English Abstract]

Ikner L.A., Toomey R.S., Nolan G., Neilson J.W., Pryor B.M. \& Maier R.M., 2007 - Culturable microbial diversity and the impact of tourism in Kartchner Caverns, Arizona. Microbial Ecology, 53: 30-42. http://dx.doi.org/10.1007/s00248-006-9135-8

Klánová K., 2002 - Standard operating procedures for the investigation of microorganisms in air and evaluation of microbial contamination in indoor air. Acta Hygienica, Epidemiologica et Microbiologica, 1: 1-20. [In Czech]

Laiz L., Groth I., Gonzalez I. \& Saiz-Jimenez C., 1999 - Microbiological study of the dripping waters in Altamira cave (Santillana del Mar, Spain). Journal of Microbiological Methods, 36: 129-138. http://dx.doi.org/10.1016/S0167-7012(99)00018-4

Matis Š., 2002 - Hibernating bats in Drienovská. Vespertilio, 6: 213-215. [In Slovak with English abstract]

Morita H., Ushiyama M., Aoyama S. \& Iwasaki M., 2003 - Sensitivity and specificity of the Sanitakun Aerobic Count: Internal validation and independent laboratory study. Journal of AOAC International, 86: 355-366.
Morita H., Ushiyama M., Aoyama S. \& Iwasaki M., 2006 - Evaluation of the Sanita-kun coliforms, a dehydrated medium sheet for coliform detection. Journal of AOAC International, 89: 399-416.

Mulec J., 2008 - Microorganisms in hypogeon: examples from Slovenian karst caves. Acta Carsologica, 37, 1: 153-160.

Mulec J., 2010 - Use of Ridacount test plates to detect human "fingerprints" in karst underground. 100 years of organized Hungarian speleology, Abstracts (Budapest 7 - 9 May 2010): 40-41.

Ritz K., 2007 - The plate debate: Cultivable communities have no utility in contemporary environment microbial ecology. FEMS Microbiology Ecology, 60: 358-362. http://dx.doi.org/10.1111/j.1574-6941.2007.00331.x

Salo S., Ehavald H., Raaska L., Vokk R. \& Wirtanen G., 2006 - Microbial surveys in Estonian dairies. LWT, 39: 460-471. http://dx.doi.org/10.1016/j.lwt.2005.03.008

Sârbu Ş.M., Kane T.C. \& Kinkle B.K., 1996 - A chemoautotrophically based groundwater ecosystem. Science, 272: 1953-1955. http://dx.doi.org/10.1126/science.272.5270.1953

Stetzenbach L.D., 1997 - Introduction to aerobiology. In: Hurst C.J., Knudsen G.R., McInerney M.J., Stetzenbach L.D. \& Walter M.V. (Eds.) - Manual of environmental microbiology. ASM Press: 619-628.

van Elsas J.D., Torsvik V., Hartmann A., Øvreås L. \& Jansson J.K. - The bacteria and archaea in soil. In: Elsas van J.D., Jansson J.K., Trevors J.T. (Eds.) - Modern soil microbiology. CRC Press: 83-105.

Verhoeff A. (ed), 1993 - EUR 14988, Report No. 12 Biological particles in indoor environments, Environment and quality of life series, Commission of European Communities: 22-34. 